\title{
COMMUNICATION OF CREATIVENESS IN BUSINESS MEDIA
}

\author{
Živilè SEDEREVIČIŪTĖ-PAČIAUSKIENE ${ }^{1 *}$, Gintare ADOMAITYTE் ${ }^{2}$, \\ Viktorija ŽILINSKAITĖ-VYTIENE் ${ }^{3}$, Vida NAVICKIENE் ${ }^{4}$, Ilona VALANTINAITÉ ${ }^{5}$ \\ 1, 2, ${ }^{3}$ Vilnius Gediminas Technical University, Faculty of Creative Industries, Department of Creative \\ Communication, Traku g. 1, LT-01132, Vilnius, Lithuania \\ 4, 5 Vilnius Gediminas Technical University, Faculty of Creative Industries, Department of Philosophy \\ and Cultural Studies, Traku g. 1, LT-01132, Vilnius, Lithuania
}

Received 28 June 2018; accepted 28 July 2018

\begin{abstract}
Creativity has been traditionally associated and even identified with artistry. However, it is being perceived as an impetus for the development of leadership and technologies innovation, and is characteristic of activities that for long have not been recognized creative. The current article presents results of the quantitative content analysis of the Business News (in Lithuanian Verslo żinios) daily business newspaper of Lithuania. The instances of the creativity concept and its synonyms use, i.e. novelty, modernity and originality, in the Lithuanian daily newspaper texts, published in 1994-2017, were calculated. The context in which these words were mentioned has been analyzed. The research results demonstrate the consistent increase in the use of the creativity concept and the related notions in texts from the chosen period. At the beginning of the period under examination, the analyzed concepts were employed in the fields traditionally related to creation and arts, such as fine arts, fashion, interior design, and advertising. Later, these concepts have entered the fields of civil engineering and information technology, i.e. the fields that had been based on knowledge and skills. Moreover, creativity notions have been used to describe inter-sectoral areas that are often initiated by project based activities. Creativity has linked entrepreneurship, information technology, innovations, and culture, and has gradually become important in texts, describing politics, education and science. The fields that had traditionally been perceived creative, have now been transformed and changed the concept of creativity, expanding the diversity of creative activities by merging them. It was found that the importance of the perception of creativity in the society, analyzed through the media content, changed in 2003, 2007 , and 2014, when creativity became crucial not only in activities traditionally related with arts, but also in business, leadership, information technology, and technology sectors, and has promoted interdisciplinarity, collaboration among sectors, as well as the pursuit of novelty, utility, and applicability.
\end{abstract}

Keywords: business media, creativity, creativity discourse, media analyses, modernity, novelty, originality.

\section{Introduction}

The 21st century is often referred to as the "age of a creative society" (Kačerauskas, 2017; Reimeris, 2016). Creativity is not only a desirable characteristic of employees, but also a feature

${ }^{\star}$ Corresponding author. E-mail: zivile.sedereviciute-paciauskiene@vgtu.lt

This is an Open Access article distributed under the terms of the Creative Commons Attribution License (http://creativecommons. org/licenses/by/4.0/), which permits unrestricted use, distribution, and reproduction in any medium, provided the original author and source are credited. 
by which products, businesses or cities are compared (Florida, 2012). Creativity has for long been associated with arts and creation and only recently the importance of this notion has started to be emphasized in business, leadership, information technology (IT), education, management, personnel management, marketing, public relations, preparation of projects and their effective functioning, etc. discourses. The creativity concept usage boundaries have been significantly expanded. This is a trend of this century, an aspiration or even the need to be both a full-fledged individual and desirable specialist in the labor market. However, these trends are being occasionally criticized with reference to the idea that nowadays, from boredom, many search for new experiences of aesthetics in anything that had long been considered traditional or even in anything that had been treated as natural results of historic causes. Is creativity a new concept in both the professional and scientific discourse? Has personal need for creativity been not as important earlier as it is today? Has creativity always been highlighted in the press?

The public texts, i.e. the press, indicats the society's expectations, thoughts, and strivings as well as the discourse authors' approach and the readership experiences that have had influenced the published texts. Every language is connected to the internal reflections within the past, thus, creating the context that presents a set of interconnected elements of the past, present and future speeches and are both mutual causes and contexts (Savinitch, 2005, p. 109). The interaction of discourse and context reveals human approaches to differences in lifestyles, institutions, objects, images, and texts; it also reveals the ways how all what is being said relates to or displays contrast with what is happening in the environment. Norman Fairclough (1995, p. 54) maintains that discourse indicates both spoken and written texts, semiotic acts - the development of meaning. According to Sean Hall (2012, p. 163), discourse is the expression means that create or reflect the social order, while the meaning acquires its shape from a context in which it is developed and used. Language is the core result of the social interaction, while words are collective results that help identify the ways humans perceive and explain both the surrounding world and certain phenomena existing therein.

Thus, any society may be analyzed through the language that reflects its culture, lifestyle, interests, and society's reciprocal power relations operating in a system. Discourse serves an intermediary: links texts with the society through discussions (Bell \& Garrett, 1998, p. 144). Editors, journalists, and front-page stories are most often perceived as a reflection of the common opinion (Bell \& Garrett, 1998, p. 21), therefore, such texts may be scrutinized to disclose discourse. This article is intended to reveal the discourse of creativity in society by analysing the content of print media. We believe that business media is the channel that reflects the public, industry and journalists' attitudes in the best way. Journalists look for the topics that are relevant to the time, responding to the readers' need to find the latest news. In this way, business media becomes a reflection of society's current issues and problems. The Business News daily business newspaper of Lithuania was chosen to investigate the discourse of creativity in order to understand how important to the society was creativity and in what contexts it was used.

The English term "creativity" was first used in 1875. Of course, cognate terms, such as "creation", "creator", "to create", had been used earlier with reference to religion and, later, with reference to artistry (Pope, 2005, p. 19). Thus, the term "creativity" is not new, and the society's striving for creativity has always been determined by both historical conditions and 
the political system that shape the individual's involvement (Pope, 2005, p. 20). Subject to the period, the term has acquired different meanings depending on the social and economic conditions, public approach and lifestyle, the role of education in human mentality and identity. There is the evolution of creativity understanding in the history of human thinking (Barevičiūte, 2014). Many scientists defined this concept differently: novelty (Perkins, 1994; Boden, 2004; Smith, 2005), aesthetics and authenticity (Kharkhurin, 2014), originality and effectiveness (Runco \& Jaeger, 2012, p. 92), influences of the environment in which people are able to work, or produce/develop creative products (Hemlin, Allwood, \& Martin, 2004, p. 1). Mark Runco and Michael D. Bahleda (1986) found differences between artists and non-artists in the characteristics they listed for different types of creativity. The relation of creativity an innovations was investigated by quite a few scholars (Sarooghi, Libaers, \& Burkemper, 2015; Joshi, 2017). We can call the innovation also as socialization of creativity (Kačerauskas, 2016, p. 37) as creativity manifests itself in society as an innovative production and becomes applicable. Today, creativity has become a widely used concept that relates to both art and industry or other spheres of human activity. However, this does not mean that creativity has previously been less important. It was important in specific areas and the scope of creativity has dramatically expanded during the past twenty years.

The aim of the paper is to analyze the change of the creativity discourse in Lithuanian print media. To answer the question of how the definition of creativity was used in various sphares of human life, four objectives were raised:

- to identify synonyms that are used to define creativity;

- to analyze the changing perception and the scope of creativity in Lithuanian print media;

- to determine fields of creative activities and social processes that have impact on the creativity concept usage in the media.

\section{Methodology}

The business daily Business News (BNs), owned by the Swedish Bonnier Group and published in Lithuania since 1994, was chosen for the media content analysis. In 1994, the daily circulation of this newspaper was approximately 75000 . In 2016, the number of online subscribers to the $B N s$, who read the publication on their computers, smart phones and other mobile devices, reached 742.742 (according to the data provided by the Internet research company Gemius). The circulation of the analyzed publication is one of the biggest in the country. The $B N s$ is the only daily business newspaper that provides quality news for about 24 years now. For the high quality presentation of business information, high journalistic ethical standards, and objective presentation of both home and world news, the newspaper has gained the positive reputation among its subscribers and is well-established in the market. The BNs news articles are also cited in other publications (IQ Magazine and Business Class (in Lithuanian Verslo klasè), Illustrated History (in Lithuanian Iliustruotoji istorija) and websites/portals, such as $w w w . c v . l t$. The $B N s$ is a prestigious publication among the Lithuanian print media.

The creativity discourse in the $B N s$ daily newspaper was examined in the period from 1994 to 2017. The study was carried out in the period of September 2014-December 2017. 
The print version of $B N s$ daily newspaper was investigated. The quantitative aspect of the creativity discourse was assessed in all the articles of BNs daily newspaper. The relevance of the quantitative creativity discourse analysis is based on Dean Simonton (2012) quantitative three-criterion definition. During the research process, both the term "creativity" and its synonyms were looked for, manualy calculating the instances of their use each year. Creativity is commonly defined as a set of criteria used to produce something novel, which has value, is adaptive, relevant to a problem and recognised (Kaufman \& Baer, 2012; Runco \& Jaeger, 2012). The following synonyms were chosen for the term "creativity": "originality", "modernity", "novelty". These synonyms are often used in the Lithuanian language to define creativity and meet the scientific discourse criteria for its definition (Perkins, 1994; Boden, 2004; Smith, 2005; Runco \& Jaeger, 2012; Martin \& Wilson, 2017). All the articles with at least single occurrence of the term "creativity" and its synonyms were classified according to the topic. The noun forms as well as adjectives, adverbs, were calculated having in mind all seven cases of singular and plural. The aim was to identify the fields for the description of which the chosen creativity synonyms had been used during a certain time period.

\section{Creativity discourse in Business News daily newspaper}

The analysis of the BNs daily newspaper texts shows the strong developmental tendencies of the creativity discourse. During the initial seven years of the daily's existence, the term "creativity" and its synonyms were infrequent. More regular and consistent occurrences of words "creativity", "originality", and "novelty" are observed in articles since 2003. Initially, the concepts were used to describe fields that are traditionally perceived creative, i.e. advertising, design, fashion, and interior design. However, gradually, creativity was established in texts on business and technologies. The analyzed period of the BNs may be divided into three stages, characterized by the intensity of the creativity discourse. The key turning points in the creativity discourse may be observed in 2003, 2007 and 2014 when the term "creativity" and its synonyms were most frequent and were used in the wider context (see Figure 1). The following is a detailed discussion of all three stages.

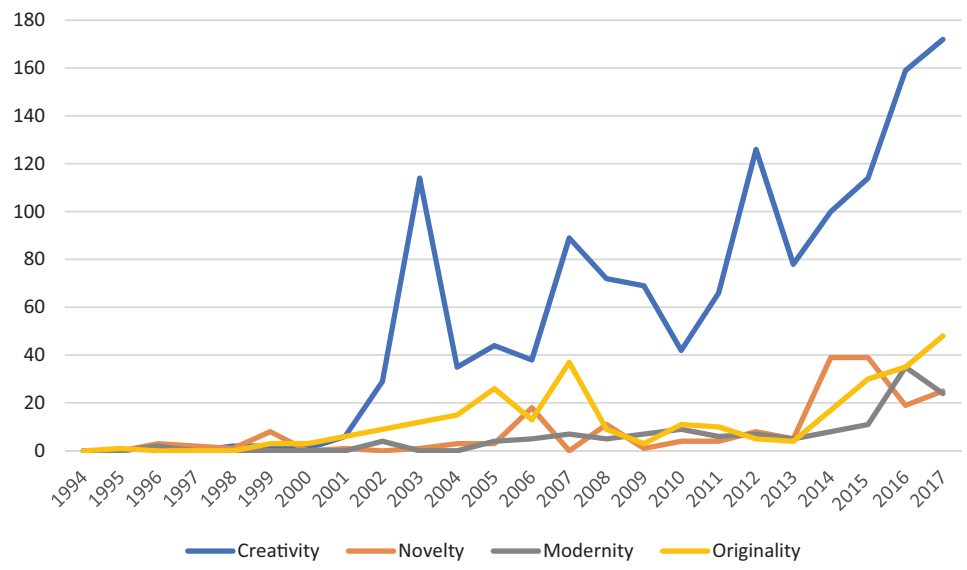

Figure 1. The term "creativity" and its synonyms usage in articles published in 1994-2017 (source: created by authors) 


\section{1994-2003: creative growth period}

The first issue of the BNs was published in 1994 and its content reflected the situation in the business market of the state that had just restored its independence. After the restoration of Lithuania's independence in 1990, a new market economy system was partly created and there was a transition to market economy. This was the period of economic recession when Lithuania's gross domestic product (GDP) has halved. This also was the period of both agricultural/rural economy and business privatization (Jakutis \& Kazlovas, 2006). The daily most often reported on the activities of companies of that time, highlighting the quantitative achievement indexes. As the private sector was making its first steps, the attempts were made to restore everything that had been destroyed. The emphasis was made on consistency and buy off, avoiding risks. During the first two initial years of the newspaper's existence, the concept of originality was mentioned only once in the articles on the establishment of foreign enterprises. In 1996 articles on advertising in publishing industry, the term "creativity" was used twice and the word "novelty" was mentioned for the first time. In 1997, the discourse was centered around "novelty" (the term was mentioned twice) in the fields of technologies and advertising.

A similar tendency is observed in the next five years, when the terms "creativity" and "novelty" are mentioned only several times. In 1998, the term "creativity" was used in the news articles on business issues. In 1999, the term "originality" was mentioned most times (8 instances) in articles on business, trademarks, marketing, design, and advertising industry. That year faced the advent of innovations and new economic strategies in Lithuania: the new legislation on small and mid-sized business enterprises came into effect (Jakutis \& Kazlovas, 2006), Lithuanian Poverty Reduction Strategy was drafted. The advertising and marketing sector faced its revival and was described as "creative" (the notion of creativity is mentioned only once that year). The second instance of the word "creativity" use is found in 1999, in the article on art galleries. The term "originality" (3 instances) is employed in articles on interior design, which told the reader that both originality and exclusiveness are very important for aesthetics and design. The term "originality" was mentioned most times in 2000. The first mention of the term is found in stories about advertising, its strategies that most efficiently influence the consumer, while the second mention is in articles on businessmen, who invest into arts and promote their revival in Lithuania. The term "creativity" is used only once in the article on business. In 2001, the texts of the daily contain the most instances of "creativity" and "originality" terms use. In this daily newspaper, creativity is most often associated with entrepreneurship, design, and advertising, while originality is associated with civil engineering innovations and IT. That year, the media covered the innovation in IT - Apple computer operation system macOS and the first version of Apple iPod. Apple Inc. company is considered the most successful example of a company that managed to merge creativity and entrepreneurship. This event has lead to a new narrative in Lithuanian texts, which relate creativity with IT innovations. The analyzed texts highlight both the creative process and its results. In 2002, the term "creativity" is mentioned 29 times in the daily's texts. Also, the terms "modernity" and "originality" are started to be used more often - 4 and 9 instances respectively. That year, $B N s$ texts defined creativity as speculation based on 
novelty, innovations, and ingenuity. 2002 also faced the advent of Mozilla 1.0, the first open access Internet browser version, which had a great impact on the further creativity discourse in the daily BNs. "Originality" was used 9 times in the articles on IT, design, and marketing. The term "modernity" was mentioned 4 times in news reports on technology innovations and IT solutions. In 2003, the texts of BNs highlighted creativity very often, as the concept was used to describe almost all fields. That year, the term "creativity" is mentioned 114 times. The terms "novelty" and "originality" are mentioned more often than the previous year and were used 15 and 9 times, respectively.

2003 is the year of Lithuanian economic growth and the reduction of unemployment, as well as the year of the final Lithuanian citizens' consent to join the European Union (EU). The state was actively preparing for the new period in its history and promoted both entrepreneurship and collaboration among the sectors. That year the term "creativity" is mentioned 114 times in BNs news stories. Thus, 2003 may be considered a turning point in the creativity discourse, as the daily started publishing articles on fields not previously related to business. From then on, a different perspective on business is taken on, i.e. business is viewed from the innovation standpoint, as creativity becomes very important. "Originality" is used 12 times in articles on the importance of originality in both the assessment of advertising and the analysis of art. In 2003, the term "novelty" was used only once in the article on design.

To sum up, in the period from 1994 to 2003, the concept of creativity was used to write about business, trademarks, marketing, design, and advertising industry, while the term "originality" was most often used in articles on arts. This is the traditional concept of creativity. 2003 faced the establishment of the creativity discourse, the context has been expanded as the term was actively used to talk about business.

\section{2004-2007: creativity discourse fields shift - from art to transport, civil engineering, and educational sciences}

2004 marks the turning point in Lithuanian politics and history: Lithuania became a member state of both the EU and NATO; also, this year marks the beginning of the economic growth of the country (Balkevicius, 2013). There are many economy, business, export, international relations, new legislation related changes that are reported in BNs issues. The term "creativity" is mentioned 35 times in articles on career, economic models, implementation of projects, i.e. in articles on different topics, taking a new standpoint on the activities of individual sectors, as well as on possible collaboration among them. In 2004, the word "originality" was used 15 times in news stories describing the importance of originality in design, business solutions, and business management. "Novelty" was mentioned 3 times in reports on global business, trade, and the importance of novelty in manufacturing.

In 2005, the creativity concept was employed 44 times in articles on trademarks, advertising industry, and business. This concept was also referred to as "freshness". The term was used in articles describing fields in which creativity helps generate value; the author describes it as "surplus value" that is one of the characteristics of the intellectual. "Originality" was employed 26 times in the articles on business, transport, and civil engineering, relating these fields with the new approach and search for alternatives. "Modernity" and "novelty" were 
used 4 and 3 times respectively in the same article on business, which claimed that the youth may suggest innovative and easily implemented ideas. In 2006, the term "creativity" was used 38 times in articles describing marketing, politics, entrepreneurship, project management and submission, advertising campaigns (e.g. Coca-Cola). It was claimed that creativity had become important even in law, everyday life, as well as in doing the chores, e.g. cooking. The word "novelty" was employed 18 times in the descriptions of publishing and entrepreneurship education expanding business topics and the necessity of scientific research for the implementation of innovative teaching/learning methods in Lithuanian educational institutions. The term "originality" was mentioned 13 times in the analysis of the synthesis of arts and business that has become a crucial subject in the development of the creative industries sector. This word was also used in news reports on fashion, arts, culture products, education system, and fostering business ideas. "Modernity" (5 instances) was mentioned in the article on new training methods for the development of students' creative thinking.

2007 marks the second turning point in the development of the creativity discourse in Lithuania. The great support from the EU investment funds to Lithuanian business has spurred on the implementation of business innovations. This determined a more frequent use of the creativity synonyms in the Lithuanian press. The term "creativity" was used 89 times in $B N s$ news stories describing the changing trends in business, project management, and importance of creativity at work, creation of advertising and the industry itself, education that aimed at making a child a successful person. This word was also employed in articles in the field of economy as well as in reviews of the gaps in the education system. "Originality" was used 37 times in news reports highlighting the appeal of a newly developed product. The term was also mentioned in the analysis of a successful business companies, their operation, competitive advantage, and related issues. This indicates a different approach to creativity as a personal characteristic. Creativity is needed in fields that had been previously driven solely by knowledge.

To sum up, it may be claimed that in the period from 2004 to 2007, the creativity discourse has not only established in the fields that had been traditionally considered creative, but also has spread to the fields that had been initially based on knowledge and skills, i.e. the fields of civil engineering and IT. "Creativity" was also observed in the inter-sectoral areas that have developed from project activities. "Creativity" has merged entrepreneurship, IT, innovations, and culture. Moreover, it became important in politics, education, and science. Thus, the term "creativity" connotes various meanings: having emerged from high art and the description of knowledge, now it has a changing connotation in the society.

\section{2008-2014: creative industries sector growth}

In 2008, the concept of creativity was used 72 times in news reports on companies' public relations activities, arts, entrepreneurship, creative thinking skills, advertising production, trademark management, and marketing. "Novelty" was employed 11 times in articles on advertising, marketing, and trademark management. "Originality" and "modernity" were mentioned 9 and 5 times respectively in topics on innovations in transport sector, implementation of new technologies. 
During the economic crisis of 2009-2011, the level of unemployment in Lithuania reached $13.7 \%$, while the country's economy and GDP encouraged people to come back to traditional business models; the purchasing power was decreasing; production and sales had to be aimed at the satisfaction of the basic needs. However, during this period, the term "creativity" usage was consistent: the term was mentioned 69, 42, and 66 times in 2009, 2010, and 2011 respectively. In 2010, Evening News (in Lithunian Vakaro žinios) started publishing articles about the merging of business and arts sectors, i.e. creative/cultural industries that would help revive economies. In 2009-2011, the term "modernity" was used in articles on trademark management, marketing, search for new alternatives, how to attract more customers with fewer costs. The concept of originality during this period was used in reports about creativity in animation, achievements in education sector, and business. The usage of the term "novelty" has significantly decreased, which indicates the need to retain activities at the already achieved levels without focusing on novelties.

2012 marks the success of Apple Inc. company, which introduced iPhone 5 into the global market. This product is considered the most professionally technical smart phone in the market, while the company itself is considered the most valued in the world. The end of the worldwide crisis and successful foreign practices inspired the country's entrepreneurs. That year, the term "creativity" was used 126 times in articles on business, project management, advertising, new sectors - creative and cultural industries. The usage of the analyzed terms is consistent in the articles: "novelty", "modernity", and "originality" were used 8, 7, and 5 times respectively. It is supposed that novelty, artistry, modernity, and originality are important for overall composition developed by the merger of business and creativity. The innovation policy in Lithuania at that time was only facing the dawn of its development. Only a few enterprises had understood the importance of innovation and its results (Pogosian \& Dzemyda, 2012). However, the growth of creative industries sector has demonstrated the need for creativity in various fields and their intersections. In 2013, creativity is mostly highlighted (78 instances) in business, IT, education, and advertising sectors. With the growth of immigration, contests are being announced and events are being organized to promote and fund the youth's entrepreneurship with not very big initial capital, but putting emphasis on creative, innovative ideas. With the development of IT sector in Lithuania, more articles on modern technologies and inventions were being published. In these articles, one may observe a consistent use of the words "novelty", "modernity", and "originality".

In 2014, in articles describing business, marketing, and advertising sectors, the word "creativity" was most frequently highlighted. These articles analyzed the future development of creative potential in Lithuania. That year may be considered the third turning point in the creativity discourse. The term "creativity" occurred 100 times in articles of the BNs, reporting on creative industries, culture, IT, design, education, advertising, and marketing. Creativity workshops were organized in the business sector; discussions about the importance of personalized marketing, design, and social media were being held. That year faced the revival of the importance of "novelty" (the term is mentioned 39 times). "Originality" was mentioned 17 times in articles on business, IT, marketing, arts, culture, and everyday life.

In 2015, the term "creativity" was used 114 times in articles on business accelerators, education, public relations, arts, and leadership. "Novelty" was employed 39 times in news stories about IT, design, and advertising industry. "Modernity" and "originality" were used 
11 and 30 times respectively in articles about art galleries and advertising. In 2016, the term "creativity" occurred 159 times in stories about career, artificial intellect, arts, business, environmental protection of workers, politics, enterprises. The term "creativity" was most often used in stories about advertising - 34 instances. "Novelty", "originality", and "modernity" were used 19, 35, and 35 times respectively. In 2017, the creativity discourse was more expanded and the term "creativity" was mentioned 172 times in news stories on leadership, enterprises' activities, workplace environment, and, especially, workforce competences. The need for creativity as a personal skill or a leader's characteristic was clearly stated in all fields. The competition in the labour market and growing demand for competent employees had provoked more publications in the BNs daily newspaper. "Modernity" was used 24 times in articles on real estate, appeal of work places, business, and innovations. "Originality" has become important in the narrative about new enterprises, directing, advertising, marketing, arts, and exhibitions. This concept was employed 49 times in the articles published in 2017.

\section{Conclusions}

Although the discourse focuses not on individuals but rather on the phenomenon, the experts and media texts developers' opinions reflect both the power of the discourse creators and the contextually changing perception of creativity. The quantitative expression of the increasing importance of creativity in business press is related to the activity field: journalists, business press editors, who evaluate and gauge the perception of creativity in the society, are unable to distance themselves from both the mainstream trends and personal experiences. The press coverage of relevant issues, events and context make an impact on media texts. Also, the texts are influenced by the readership, who have the power to choose which texts to read, thus, influencing the production of those texts. Hence, the context, readership, and author are interrelated and influence one another (Leech \& Short, 2007; Hall, 2012; Dijk, 2009). The usage of the term "creativity" in the publication not related to arts indicates a shift in the creativity discourse: the composition of texts is based on words that attract and interact with the readership. This inspires public discussions as well as shaping and dispersal of the public opinion that provides the context for the development and advocacy of meanings.

The term "creativity" has for long been abandoned in the field of culture. This is both shocking and amazing (Pope, 2005, p. 24). Nevertheless, both art and culture have been the first fields that much valued creativity.

At the beginning, creativity in the $B N s$ daily newspaper articles was traditionally associated with arts. Later the term was perceived as one of the most important constituent parts of innovations, leadership, IT, project and education areas. As maintained in Richard Florida (2005, p. 26), the society enters the age of creativity in which the importance of creative economy growth is considered to be a key factor for encouraging the further development. The change in the perception of arts and business relationship encourages the synthesis of artistry and aesthetics, technology and entrepreneurship, expressed by new collocations, such as "creative economy", "creative society", "innovative product", and "creative solution". These new collocations are used in the 21st century to refer to arts, advertising, education, business, leadership, IT and technologies, design, and creative industries. Starting from the first pilot issue of the BNs daily business newspaper, there may be observed a growing number 
of instances of the term "creativity" use in the articles: a creative business, technological inventions, science and research are mentioned more often. Moreover, creativity is frequently mentioned in articles about the development of work places, recruitment, and career.

The importance of the perception of creativity in the society, analyzed through the media content, changed in 2003, 2007, and 2014, when creativity became crucial not only in activities traditionally related with arts, but also in business, leadership, IT, and technology sectors, and has promoted interdisciplinarity, collaboration among sectors, as well as the pursuit of novelty, utility, and applicability. Business journalism, specifically the $B N s$, is oriented at a wide range of activities and is thematically focused on business, innovations, advertising, and marketing. However, this daily also publishes articles on design, fashion, and education. The analysis of the BNs articles published in the period of 24 years has shown some turning points in the society, which were reflected by the growing and consistent use of the term "creativity" and its synonyms ("modernity", "artistry", "novelty", "originality") in the daily's news stories.

The investigation of creativity discourse through the media text analysis as well as the creators' perception and evaluations offers an opportunity to learn how the term "creativity" is used in the press and how it is perceived by authors of texts. The analyzed creativity discourse in the Lithuanian media leads to the conclusion about the shift in creativity in general. There is a need for further research in the international context, demonstrating the creativity discourse change in foreign media, which would lead to further insights and more global conclusions. The use of the creativity concept in Lithuanian media research, including both the media creators and audience, demonstrates the extent to which this concept is used in various fields and allows both employers and employees better perceive creativity. Spoken and written texts are equally important for the formation and functioning of the creativity discourse in the society. Media texts are exposed to and have an impact on the society's perception.

The study of creativity discourse, using media text analysis and perceptions of text authors, provides an opportunity to find out how the term "creativity" is defined and questioned in the press, with what meanings, activities it is associated by media writers and users. Based on the data obtained during the study, practical proposals can be made for the classification and definition of creative activities and its interconnectivity. The limits of creativity are expanding, and people are discussing creative products, their aesthetic and material value. It is important to take a closer look at the perceptions of contemporary creativity and to anticipate its future benefits and transformations.

\section{References}

Balkevicius, A. (2013). Lithuanian financial system transformation in the context of globalization. Trends Economics and Management, 7(14), 14-21.

Barevičiūtè, J. (2014). Pagrindiniai kūrybiškumo ir kūrybingumo aspektai šiuolaikiniuose humanitariniuose bei socialiniuose moksluose. Filosofija. Sociologija, 25(1), 19-28.

Bell, A., \& Garrett, P. (Eds.). (1998). Approaches to media discourse. Oxford: Blackwell Publishers Ltd.

Boden, M. A. (2004). The creative mind: myths and mechanisms. London and New York: Routledge. https://doi.org/10.4324/9780203508527

Dijk, van T. A. (2009). News as discourse. Series: Communication. D. Zillmann \& J. Bryan (Eds.). New York and London: Routletge. 
Fairclough, N. (1995). Media discourse. London: Edward Arnold.

Florida, R. (2005). The flight of the creative class: the new global competition for talent. New York: HarperCollins Publishers. https://doi.org/10.4324/9780203997673

Florida, R. (2012). The rise of the creative class, revisited. New York: Basic Books.

Hall, S. (2012). This means this, this means that: a user's guide to semiotics. London: Laurence King Publishing Ltd.

Hemlin, S., Allwood, C. M., \& Martin, B. R. (2004). Creative knowledge environments: the influences on creativity in research and innovation. Cheltenham: Edward Elgar Publishing.

Jakutis, A., \& Kazlovas, V. (2006). Lietuvos ūkio ir verslo raidos analizè. Verslas: teorija ir praktika, 7(3), 163-167. https://doi.org/10.3846/btp.2006.20

Joshi, M. (2017). Creativity and innovation. SSRN. Retrieved from https://poseidon01.ssrn.com/delivery.php? https://papers.ssrn.com/sol3/papers.cfm?abstract_id=2993084

Kačerauskas, T. (2017). Kreativnost i koncepciya kreativnovo obščestva v sociologii. Sotsiologicheskie issledovaniya, 10, 26-35.

Kačerauskas, T. (2016). The paradoxes of creativity management. Ekonomika a management, 19(4), 33-43. https://doi.org/10.15240/tul/001/2016-4-003

Kaufman, J. C., \& Baer, J. (2012). Beyond new and appropriate: who decides what is creative?. Creativity Research Journal, 24(1), 83-91. https://doi.org/10.1080/10400419.2012.649237

Kharkhurin, A. V. (2014). Creativity.4in1: four-criterion construct of creativity. Creativity Research Journal, 26(3), 338-352. https://doi.org/10.1080/10400419.2014.929424

Leech, G., \& Short, M. (2007). Style in fiction: a linguistic introduction to English fictional prose. Series: English Language Series. R. Quirk (General Ed.). Harlow: Pearson Education Limited.

Martin, L., \& Wilson, N. (2017). Defining creativity with discovery. Creativity Research Journal, 29(4), 417-425. https://doi.org/10.1080/10400419.2017.1376543

Perkins, D. N. (1994). Creativity: beyond the Darwinian paradigm. In M. A. Boden (Ed.), Dimensions of creativity (pp. 119-142). London: Massachusetts Institute of Technology.

Pogosian, S., \& Dzemyda, I. (2012). Inovacijos versle ir jas lemiantys veiksniai teoriniu ir politiniu aspektu. Ekonomika ir vadyba: aktualijos ir perspektyvos, 1(25), 63-76.

Pope, R. (2005). Creativity: theory, history, practice. London and New York: Routledge.

Reimeris, R. (2016). Theoretical features of the creative society. Creativity Studies, 9(1), 15-24. https://doi.org/10.3846/23450479.2015.1088902

Runco, M. A., \& Bahleda, M. D. (1986). Implicit theories of artistic, scientific, and everyday creativity. Journal of Creative Behavior, 20(2), 93-98. https://doi.org/10.1002/j.2162-6057.1986.tb00423.x

Runco, M. A., \& Jaeger, G. J. (2012). The standard definition of creativity. Creativity Research Journal, 24(1), 92-96. https://doi.org/10.1080/10400419.2012.650092

Sarooghi, H., Libaers, D., \& Burkemper, A. (2015). Examining the relationship between creativity and innovation: a meta-analysis of organizational, cultural, and environmental factors. Journal of Business Venturing, 30(5), 714-731. https://doi.org/10.1016/j.jbusvent.2014.12.003

Savinitch, L. (2005). Pragmatic goals and communicative strategies in journalistic discourse under censorship. In E. Grillo (Ed.), Power without domination: dialogism and the empowering property of communication. Series: Discourse Approaches to Politics, Society and Culture. Vol. 12 (pp. 107-138). Amsterdam/Philadelphia: John Benjamins Publishing Company. https://doi.org/10.1075/dapsac.12.07sav

Simonton, D. K. (2012). Taking the U.S. Patent Office criteria seriously: a quantitative three-criterion creativity definition and its implications. Creativity Research Journal, 24(2-3), 97-106.

Smith, G. J. W. (2005). How should creativity be defined?. Creativity Research Journal, 17(2-3), 293-295. https://doi.org/10.1080/10400419.2005.9651487 


\section{KŪRYBIŠKUMO KOMUNIKACIJA VERSLO MEDIJOSE}

\section{Živilè SEDEREVIČIŪTĖ-PAČIAUSKIENĖ, Gintarè ADOMAITYTĖ, Viktorija ŽILINSKAITÉ-VYTIENÉ, Vida NAVICKIENĖ, Ilona VALANTINAITÉ}

\section{Santrauka}

Viena vertus, kūrybiškumas tradiciškai siejamas ar netgi tapatinamas su meniškumu, kita vertus, suvokiamas kaip inovacijų, lyderystės, technologijų raidos stimulas, būdingas veiklos rūšims, ilgą laiką nesuvoktoms kaip kūrybiškoms. Straipsnyje pateikiami verslo dienraščio kiekybinès turinio analizès rezultatai. 1994-2017 metų Lietuvos dienraščio tekstuose buvo suskaičiuotos kūrybiškumo sąvokos ir jo sinonimai - naujumas, modernumas ir originalumas. Lietuviškas dienraštis Verslo žinios buvo pasirinktas medijų turinio analizei, kiekviename jo numeryje buvo suskaičiuotos visos kūrybiškumo ir jo sinonimų sąvokos. Tyrimo rezultatai rodo nuoseklų kūrybiškumo ir su juo susijusių sąvokų vartojimo augimą tekstuose visu tiriamuoju laikotarpiu. Laikotarpio pradžioje sąvokos buvo vartojamos tik su kūryba ir menu tradiciškai siejamose srityse, tokiose kaip dailè, mada, interjeras, reklama. Vèliau sąvokų vartojimas paplito srityse, kuriose anksčiau reikèjo tik žinių ir igūdžių - statyboje, informacijos technologijose. Kūrybiškumas pradètas įžvelgti aprašant tarpsektorines sritis, kurios neretai startavo pasitelkiant projektinę veiklą. Kūrybiškumas susiejo verslumą, informacijos technologijas, inovacijas ir kultūrą. Palaipsniui kūrybiškumas tapo svarbus politiką, švietimą ir mokslą aprašančiuose tekstuose. Sritys, kurios tradiciškai buvo suvokiamos kaip kūrybiškos, ėmè transformuotis, keisdamos ne tik kūrybiškumo sampratą, bet ir didindamos kūrybiškos veiklos rūšių spektrą bei jų susivienijimą / suliejimą tarpusavyje. Kūrybiškumo svarbos visuomenèje suvokimas, analizuotas per medijų turini, pakito 2003, 2007 ir 2014 metais, kūrybiškumui tampant esminiu ne tik tradiciškai su menu siejamoje veikloje, bet ir versle, lyderysteje, informacijos ir kitų technologijų srityse, skatinant tarpdiscipliniškumą, tarpsektorinị bendradarbiavimą bei naujumo, naudingumo ir pritaikomumo siekimą.

Reikšminiai žodžiai: verslo medijos, kūrybiškumas, kūrybiškumo diskursas, medijų analizè, modernumas, naujumas, originalumas. 